\title{
Elk and Mule Deer Diets in North-Central New Mexico
}

\author{
Leonard Sandoval, ${ }^{1}$ Jerry Holechek, ${ }^{2}$ James Biggs, ${ }^{3}$ \\ Raul Valdez, ${ }^{4}$ and Dawn VanLeeuwen ${ }^{5}$ \\ Authors are ${ }^{1}$ Graduate Student and ${ }^{2}$ Professor, Department of Animal and Range Sciences, New Mexico State University, \\ Las Cruces, NM 88003; ${ }^{3}$ Research Scientist, Los Alamos National Laboratory, Los Alamos, NM 87544; ${ }^{4}$ Professor, \\ Department of Fishery and Wildlife Sciences, New Mexico State University, Las Cruces, NM 88003; and \\ ${ }^{5}$ Associate Professor, Experimental Statistics, New Mexico State University, Las Cruces, NM 88003.
}

\begin{abstract}
Botanical composition of mule deer and elk diets in winter, spring, summer, and autumn was studied during 1998 and 1999 on woodland rangeland in north-central New Mexico using microhistological analysis of fecal samples. Our study area had no livestock grazing for 60 years but was moderately grazed by mule deer and elk. Elk and mule deer shared 3 of the top 5 key forage species when diets were pooled across seasons and years. These 3 species were oak (Quercus sp.), ponderosa pine (Pinus ponderosa Dougl.), and mullein (Verbascum thapsus L.). When data were pooled across seasons and years, overall dietary overlap between mule deer and elk was $64 \%$. Diet overlaps of $50 \%$ or more occurred between mule deer and elk in all 4 seasons in both years of study. Throughout both years, mule deer and elk diets were dominated by browse. Mountain mahogany (Cercocarpus montanus Raf.) was the most abundant browse plant in mule deer diets; ponderosa pine was most abundant in elk diets. Both animals selected forbs, which were in low supply during the study. Scarlet globemallow (Sphaeralcea coccinea Pursh), a nutritious forb, was common in both mule deer and elk diets. Our study and others from woodland rangelands in New Mexico show high potential for forage competition between mule deer and elk. Elk are more dietarily adaptable to changing forage availability than are mule deer. Our study indicates that diets of mule deer and elk are not complementary on woodland rangelands in New Mexico. Therefore, grazing capacity is not increased by common-use grazing of the 2 animals. Both mule deer and elk herds have been increasing on our study area. Therefore, if use of common forage species is kept at moderate levels on southwestern woodland rangelands, mule deer herds can be maintained or increased when elk are present.
\end{abstract}

\section{Resumen}

La composición botánica de las dietas de invierno, primavera, verano y otoño de ciervos rojos (Cervus elaphus) y venados (Odocoileus hemonius) que habitan en los pastizales de monte del centro-norte de Nuevo México fue estudiada durante 1998 y 1999 utilizando análisis microhistológico delas heces. Nuestra área de estudio estuvo excluida del pastoreo bovino por 60 años pero recibió pastoreo moderado de venados y ciervos rojos. Los ciervos rojos y venados compartieron 3 de las 5 especies forrajeras claves más importantes cuando se analizaron las dietas combinadas de todas las estaciones y de ambos años. Estas tres especies fueron roble (Quercus sp.), pino ponderosa (Pinus ponderosa Dougl.), y barbasco (Verbascum thapsus L.). Cuando se combinaron los datos de todas las estaciones y años, el traslape de la dieta entre el ciervo rojo y el venado fue del $64 \%$. El traslape de la dieta del $50 \%$ o más ocurrio en las 4 estaciones y en ambos años de este estudio. A lo largo de ambos años, tanto las dietas de venados como las de ciervos rojos estuvieron dominadas por forraje ramoneable. Cercocarpus montanus Raf. (mountain mahogany) fue la especie arbustiva más abundante en la dieta de venados, mientras que pino ponderosa fue la especie más abundante en dietas de ciervos rojos. Ambos herbívoros seleccionaron hierbas cuya disponibilidad fue baja durante este estudio. Sphaeralcea coccinea Pursh (scarlet globemallow), una hierba nutritiva, se halló frecuentemente tanto en las dietas de venados como de ciervos rojos. Nuestro estudio así como otros realizados en los pastizales de monte de Nuevo México demuestran alto potencial de competencia dietaria entre venados y ciervos rojos. Los ciervos rojos se adaptan más fácilmente que los venados a cambios en la disponibilidad forrajera. Nuestro estudio demuestra que las dietas de venados y ciervos rojos que habitan pastizales de monte de Nuevo México no son complementarias. Por lo tanto, la capacidad de pastoreo no puede incrementarse mediante el uso común de estos 2 herbívoros. Tanto los venados como los ciervos rojos se han estado incrementando en nuestra área de estudio. Por lo tanto, si el uso de forraje frecuentemente pastoreado en pastizales de monte del sudoeste se mantiene en niveles moderados, las poblaciones de venados pueden ser mantenidas o incrementadas en la presencia de ciervos rojos.

Key Words: rangelands, forage, wildlife, competition, grazing

\section{INTRODUCTION}

This research was supported by the New Mexico Agricultural Experiment Station, New Mexico State University, and was part of Project 072944.

Correspondence: Jerry Holechek, Animal and Range Sciences Dept, New Mexico State University, Las Cruces, NM 88003. Email: holechek@nmsu.edu

Manuscript received 13 May 2004; manuscript accepted 22 February 2005.
During the past 30 years Rocky Mountain elk (Cervus elaphus Nelson:Bailey) have steadily increased in New Mexico while mule deer populations (Odocoileus hemionus Rafinesque) have declined based on New Mexico Department of Game and Fish annual winter surveys. Various factors have been implicated in 
the decline of mule deer in New Mexico. These include habitat loss from urbanization, loss of understory vegetation from increased tree cover on woodlands, excessive harvest, increased predation, and increased elk populations (Carpenter 1997; De Vos et al. 2003). In portions of New Mexico, mule deer have declined in areas where habitat quality appears high and urbanization impacts are minimal (Harrod 1998a, Harrod 2002). In most of these areas elk populations have greatly increased (Harrod 1998b, Harrod 2002). Competition for forage between elk and mule deer may be an important contributing factor in the mule deer decline on some New Mexico rangelands (Tafoya 2000).

Knowledge and understanding of food habits are fundamental in management of large ungulates (Kufeld 1973; Holechek et al. 1982). They provide important information on primary forage plants, diet quality, and competitive relationships. Knowledge of seasonal food habits is essential for understanding and evaluating carrying capacity of large herbivores such as elk and mule deer (Leslie et al. 1984; Hobbs and Carpenter 1986). Studies evaluating elk and mule deer food habits and competitive relationships on woodland rangelands in northern New Mexico are lacking. The objective of our study was to determine the botanical composition of seasonal diets of elk and mule deer, dietary overlap, and diet variations among seasons and years. Studies were conducted on the Los Alamos National Laboratory (LANL) in north-central New Mexico. Ponderosa pine (Pinus ponderosa Dougl.) and piñon-juniper (Pinus edulis Engelm.-Juniperus monosperma Engelm.) woodlands are the principle vegetation types on our study area. These vegetation types are primary habitat for mule deer and elk in most of New Mexico.

\section{MATERIALS AND METHODS}

\section{Study Area}

Our study area is located on the LANL in north-central New Mexico about $128 \mathrm{~km}$ north of Albuquerque and $40 \mathrm{~km}$ northwest of Santa Fe (UTM NAD 83: Easting 381607, Northing 3968663). The LANL, covering about $69 \mathrm{~km}^{2}$, is located on the Pajarito Plateau on the eastern flanks of the Jemez Mountains. The eastern extension of the Pajarito Plateau consists of several fingerlike mesas and canyons, bounded to the east by the Rio Grande River. The LANL is bordered to the south by Bandelier National Monument, managed by the US National Park Service; US Forest Service property lies to the west, and to the east is the Pueblo of San Ildefonso. Two populated areas, the Los Alamos and White Rock town sites, are adjacent to LANL to the north and southeast, respectively.

Past disturbances in the study area and on the Pajarito Plateau include grazing by sheep, cattle, goats, and horses from the early 16th century until the mid-1940s, when livestock were removed from the LANL (Tierney and Foxx 1982). Agriculture in the higher regions of the Pajarito Plateau began in the late 1800s and continued until the mid-1940s, when the federal government appropriated homesteads in the area. The Pajarito Plateau was subjected to heavy logging from approximately 1900 until the mid-1940s (Tierney and Foxx 1982). Hunting has not been allowed on the LANL since the mid-1940s.
During the past 25 years over 32375 ha of forested land has been burned by wildfires on the Pajarito Plateau and the east Jemez Mountains. These fires were largely a result of increased fuel loading due to prior fire suppression (White 1981; Foxx 2000).

\section{Climate}

LANL has a semiarid, temperate mountain climate (Bowen 1990). Summer day temperatures are usually between $21^{\circ}$ and $27^{\circ} \mathrm{C}$ and occasionally reach $32^{\circ} \mathrm{C}$. Winter temperatures are usually between $1^{\circ}$ and $10^{\circ} \mathrm{C}$ during the day and between $-9^{\circ}$ and $-4^{\circ} \mathrm{C}$ during the night.

Typically, the greatest percentage of rainfall is received during the warmest months of the year. More than half of the annual precipitation is received between May and October, with $36 \%$ or more occurring during July and August (Bowen 1990). Winter precipitation occurs as snow, with average accumulations of about $1500 \mathrm{~mm}$ seasonally (Bowen 1990). Average annual precipitation at Los Alamos town site is 480 $\mathrm{mm}$, but has ranged from 170 to $770 \mathrm{~mm}$ over a 71 -year period (Bowen 1990). Total annual precipitation on the study area in 1998 was $440 \mathrm{~mm}$, or $92 \%$ of the long-term average. In 1999 total annual precipitation on the study area was $410 \mathrm{~mm}$, or $85 \%$ of the long-term average.

Elevation of the study area ranges from 1981 to $2286 \mathrm{~m}$. The lowest elevation occurs to the northeast of the White Rock town site along Pajarito Road and the highest elevation occurs near the southwest boundary of LANL along Highway 501.

\section{Vegetation}

Piñon-juniper woodlands are the dominant vegetation between 1767 and $2134 \mathrm{~m}$ (Tierney and Foxx 1980; Balice et al. 1997). Piñon-juniper woodlands range from open- to closed-canopy communities (Tierney and Foxx 1984). They can be found as high as $2194 \mathrm{~m}$ on south-facing slopes (Balice et al. 1997). The dominant tree species are one-seed juniper and piñon pine. Oneseed juniper is dominant at lower elevations with piñon pine dominant at higher elevations (Balice et al. 1997). Other tree species are rare. The most common shrubs are oaks (Quercus gambelii Nutt. and Quercus undulata Torr.), mountain mahogany (Cercocarpus montanus Raf.), wormwood (Artemesia ludoviciana Nutt.), skunkbush sumac (Rhus trilobata Nutt.), and wax current (Ribes cereum Dougl.) (Tierney and Foxx 1982). Common grasses are blue grama (Bouteloua gracilis [H.B.K.] Lag. Ex Steud.), needleandthread (Stipa comata Trin. \& Rupr.), galleta (Hilaria jamesii [Torr.] Benth), ring muhly (Mulenburgia torreyi Kurth.), and mountain muhly (Mulenbergia montana Nutt.) (Tierney and Foxx 1982; Balice et al. 1997). Common forbs include bitterweed (Hymonoxys argentea DC.), white ragweed (Hymenopappus filfolius DC.), and leafy goldenaster (Chrysopis villosa Pursh) (Tierney and Foxx 1982).

Ponderosa pine forests extend from 1890 to $2377 \mathrm{~m}$ and occupy the western one-third of LANL (Tierney and Foxx 1982, Balice et al. 1997). Ponderosa pine, the dominant tree species, ranges from dog-hair thickets to open stands. The understory is composed mostly of grasses and sedges such as mountain muhly, little bluestem (Schyzachyrium scoparium [Michx] Nash), pine dropseed (Blepharneuron tricolepis [Torr.] Nash), and wheatgrass species (Agropyron spp.) (Tierney and Foxx 1982; Balice 
et al. 1997). Gambel oak (Quercus gambelii Nutt.), bearberry (Arctostaphylos uva-ursi [L.] Spreng), and Colorado barberry (Berberis fendleri Nutt.) are the 3 most common shrubs. Common forbs include pussytoes (Antennaria parvifolia L.) and Fremont's goosefoot (Chenopodium fremontii Wats.).

Vegetation cover data collected on the study area shown in Table 1 provide an indication of vegetation composition for our study site. However, we caution that this information is of limited value in terms of characterizing selective foraging behavior. This is because these data were collected in years prior to our study and may not reflect exactly what was available on sites of animal foraging.

Qualitative assessments of combined elk and deer grazing intensity on the LANL study area were made in May of 1998 and 1999 following procedures of Holechek and Galt (2000). Based on these assessments, overall grazing intensity on forage species was considered moderate in both years.

\section{Experimental Procedures}

During summer 1998, 13 permanent pellet plots were randomly placed on mesa tops and in canyon bottoms dominated by piñon-juniper or ponderosa pine on our LANL study area. Pellet plots were $20 \mathrm{~m} \times 20 \mathrm{~m}$ in size and marked at each corner with a permanent metal rebar stake.

Collection of pellet samples was initiated during summer 1998 and completed in spring 2000. Each year pellet samples were collected on all 13 plots in summer (16 June-15 September), autumn (16 September-15 December), winter (16 December-15 March), and spring (16 March-15 June). At the beginning of each season, all pellet plots were cleared of existing fecal material. This was done to avoid resampling the same pellets the following season. Pellet size and shape were used to differentiate between elk and mule deer (Bubenik 1982). We attempted to obtain a sample from each plot involving a composite of 5 pellets from 5 different fecal groups per season for both elk and mule deer. Our goal was to have at least 3 plots with fecal samples from each animal for each season. This goal was met in all seasons but one. For mule deer we obtained only 2 samples in spring 1999. In some cases our composite fecal sample from particular plots involved less than 5 different fecal groups because we could not find 5 fecal groups for a particular animal species.

\section{Slide Preparation}

Preparation of reference slides from ground plant material and slides from ground pellet samples were prepared using the method developed by Sparks and Malechek (1968) as modified by Holechek (1982), Holechek and Gross (1982a, 1982b), and Alipayo et al. (1992). Kaiser glycerine jelly was used to mount the slides; mounting was based on the procedure described by Joseph (1995).

\section{Fecal Analysis}

Botanical composition of mule deer and elk fecal samples was determined for years (1998 and 1999) and seasons (summer, autumn, winter, and spring) using microhistological analysis (Dearden et al. 1975; Alipayo et al. 1992). Five slides from 3 randomly chosen samples (pellet plots) for each year-season combination (47 total samples) were analyzed by systematically
Table 1. Percent cover of the primary forage species and their mean percent contribution to mule deer and elk diets for data pooled across years (1998 and 1999) and seasons (winter, spring, summer, and autumn) on the Los Alamos National Research Laboratory.

\begin{tabular}{|c|c|c|c|}
\hline Lifeform/species & Cover $^{1}$ & Elk $\operatorname{diet}^{2}$ & $\begin{array}{c}\text { Mule deer } \\
\text { diet }^{2}\end{array}$ \\
\hline & \multicolumn{3}{|c|}{ 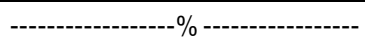 } \\
\hline \multicolumn{4}{|l|}{ Shrubs/trees } \\
\hline One-seed juniper (Juniperus monosperma) & 8 & 2 & 4 \\
\hline Oak species (Quercus spp.) & 12 & 11 & 12 \\
\hline \multicolumn{4}{|l|}{ Mountain mahogany (Cercocarpus } \\
\hline montanus) & 4 & $5^{\mathrm{a}}$ & $16^{\mathrm{b}}$ \\
\hline Apache plume (Fallugia paradoxa) & 3 & 3 & 3 \\
\hline Russian olive (Elaeagnus angustifolia) & 1 & $4^{\mathrm{a}}$ & $12^{\mathrm{b}}$ \\
\hline Skunkbush sumac (Rhus trilobata) & 3 & 2 & 6 \\
\hline Piñon pine (Pinus edulis) & 11 & $\mathrm{~T}^{3}$ & 2 \\
\hline Coyote willow (Salix exigua) & 5 & 2 & 0 \\
\hline Ponderosa pine (Pinus ponderosa) & 15 & 9 & 9 \\
\hline \multicolumn{4}{|l|}{ Rubber rabbitbrush (Chrysothamnus } \\
\hline nauseosus) & 2 & $\mathrm{~T}$ & T \\
\hline Big sagebrush (Artemisia tridentata) & 3 & 2 & 0 \\
\hline Total shrubs & 68 & $44^{\mathrm{a}}$ & $67^{b}$ \\
\hline \multicolumn{4}{|l|}{ Forbs } \\
\hline Mullein (Verbascum thapsus) & $\mathrm{T}$ & 9 & 7 \\
\hline Annual sunflower (Helianthus annuus) & 0 & 2 & 2 \\
\hline Scarlet globemallow (Spaeralcea coccinea) & 0 & 4 & 6 \\
\hline \multicolumn{4}{|l|}{ Purple prairie clover (Petalostemum } \\
\hline purpureum) & 0 & 2 & 4 \\
\hline Total forbs & 3 & 25 & 28 \\
\hline \multicolumn{4}{|l|}{ Grasses } \\
\hline Junegrass (Koelaria macrantha) & $\mathrm{T}$ & $6^{\mathrm{a}}$ & $0^{\mathrm{b}}$ \\
\hline Longstyle rush (Juncus longystylus) & 0 & 2 & 0 \\
\hline Carex species (Carex spp.) & 8 & $\mathrm{~T}$ & 0 \\
\hline \multicolumn{4}{|l|}{ Slender wheatgrass (Agropyron } \\
\hline trachycaulum) & T & 4 & 2 \\
\hline Mutton grass (Poa fendleriana) & 6 & 7 & 0 \\
\hline Fescue species (Festuca spp.) & 0 & 5 & 0 \\
\hline Blue grama grass (Bouteloua gracilis) & 10 & $\mathrm{~T}$ & $\mathrm{~T}$ \\
\hline Orchard grass (Dactylis glomerata) & $\mathrm{T}$ & 3 & 2 \\
\hline Total grasses & 29 & $31^{\mathrm{a}}$ & $5^{\mathrm{b}}$ \\
\hline \multicolumn{4}{|c|}{$\begin{array}{l}\text { 1' }{ }^{1} \text { over data were pooled from previous surveys conducted at } 8 \text { locations within the study } \\
\text { area (Salisbury 1995; Biggs 1996; Foxx 1996; Raymer 1996). Cover data were collected } \\
\text { in August and early September. } \\
{ }^{2} \text { Diets were pooled across seasons and years. } \\
{ }^{3} \text { T indicates trace. } \\
\text { a,b Means with different lowercase letters within the same row are significantly different } \\
\text { at } P<0.05 \text {. }\end{array}$} \\
\hline
\end{tabular}

viewing 20 fields per slide at $\times 100$ to $\times 200$ magnification under a compound phase-contrast binocular microscope (Sparks and Malechek 1968; Todd and Hansen 1973; Gretchen and Dahl 1980). The frequency addition method developed by Holechek and Gross (1982a) was used to quantify botanical composition.

The microscope observer was trained using the procedure developed by Holechek and Gross (1982b). Observer accuracy was established using hand-compounded diets (Holechek and 
Gross 1982b). Observer similarity in estimating the composition of hand-compounded diets was about $85 \%$ and recognition capability of primary forage species was near $100 \%$.

We used previous surveys of plant cover to characterize vegetation composition on our study area (Salisbury 1995; Biggs 1996; Foxx 1996; Raymer 1996). These surveys were conducted during August and early September. Percent cover of browse was collected using the line-intercept method along 30.5-m line transects. Percent cover of forbs and grasses was collected along the same line transect at every $305 \mathrm{~cm}$ using a $20 \times 50 \mathrm{~cm}$ Daubenmire frame to visually estimate cover.

Differences in the consumption of plant species among animal species, seasons, and years were determined using a randomized factorial analysis of variance (Steel and Torrie 1980). This analysis involved 2 animal species (mule deer and elk), 4 seasons (winter, spring, summer, and autumn), 2 years (1998 and 1999), and 3 replications (pellet plots). Total sample size was 47 because we only obtained 2 samples for mule deer in spring 1999. Similarity indices (Oosting 1956) as applied to dietary analyses (Olsen and Hansen 1977) were used to quantify overlap of mule deer and elk diets within seasons and years.

\section{RESULTS AND DISCUSSION}

Oak, ponderosa pine, mountain mahogany, Russian olive (Elaeagnus angustifolia L.), mullein (Verbasum thapsus L.), and scarlet globemallow (Sphaeralcea coccinea Pursh) were predominant forage species in both mule deer and elk diets (Table 1). These species composed $4 \%$ or more of the diet of each animal species. Junegrass (Koeleria macrantha Lam.), muttongrass (Poa fendleriana [Steud.] Vasey), and fescue (Festuca sp.) were present in elk diets but not in mule deer diets. All common forage plants in mule deer diets were also important in elk diets except skunkbush sumac. Mule deer consumed significantly $(P<0.05)$ more browse than elk; elk consumed significantly more $(P<0.05)$ grass than mule deer.

Seasonal diets of elk were more diverse than those of mule deer. Elk consumed a total of 40 species compared to 26 species for mule deer. During the 2-year study, mule deer consumed 12 species of shrubs, 10 forbs, and 4 grasses. Elk consumed 14 species of shrubs, 12 forbs, and 14 grasses.

When data were pooled across seasons and years, overall dietary similarity between mule deer and elk was $64 \%$. Mule deer and elk shared 3 of the 5 most important species in their diets (oak, mullein, and ponderosa pine). These data indicate high potential for forage competition between mule deer and elk on the LANL. When 2 animals share 3 or more of the 5 primary forages in their diets and dietary overlaps are $50 \%$ or more, grazing capacity is considered nonadditive (Holechek et al. 2004). This means that, because of high similarity in their diets, common-use grazing by the 2 animal species does not increase grazing capacity. Mule deer and elk in our study met these conditions.

Our data are consistent with various other studies reviewed by Kufeld et al. (1973), Urness (1981), and Wallmo and Regelin (1981) that show mule deer consume primarily shrubs and forbs and restrict their consumption of grasses. Although shrubs were the primary forage class consumed by elk, grasses and forbs were also important dietary components. Based on reviews by Kufeld (1973) and Nelson and Leege (1982a, $1982 \mathrm{~b})$, elk have considerable capability to adjust their food habits in accordance with changing forage availability. However, most studies have shown elk to be more of a grazing than browsing animal (Kufeld 1973; Nelson and Leege 1982a, 1982b).

Mule deer lack capability to digest grasses because of their small rumen-to-body-weight ratio (Hanley 1982). In New Mexico, confined mule deer experienced digestive problems and had depressed forage intake when forced to eat high-grass diets (Mubanga et al. 1985). Conversely, mule deer fed highforb and -shrub diets (similar in crude protein content to the grass diets) had no digestive problems and higher intakes than the mule deer that were fed grass diets.

Both mule deer and elk diets showed high similarity between years. Dietary overlap between years was over $70 \%$ for both deer and elk. There were no animal species by year interactions $(P>0.5)$ for any dietary component. Shrub, forb, and grass consumption did not differ $(P>0.05)$ between 1998 and 1999 for either mule deer or elk. Both deer and elk consumed more $(P<0.05)$ skunkbush sumac and scarlet globemallow in 1999 than in 1998. The lack of dietary difference between years for both deer and elk is explained by precipitation amount and timing being similar in 1998 and 1999. Therefore, timing and amount of forage growth did not change greatly between years.

Mule deer did not shift $(P>0.05)$ their consumption of grasses, forbs, and shrubs among seasons (Table 2). However, they did alter $(P<0.05)$ their consumption of oak, mountain mahogany, Russian olive, skunkbush sumac, ponderosa pine, mullein, annual sunflower (Helianthus annus L.), scarlet globemallow, and purple prairie clover (Petalostemum purpureum Vent.) with season. Mullein and purple prairie clover are tall, robust, upright forbs. They were probably important in winter mule deer diets because they were not completely covered with snow.

Our study is consistent with other studies in showing New Mexico mule deer diets are dominated by browse throughout the year (Mahgoub et al. 1987; Tafoya 2000). This is explained by low availability of high quality forbs such as scarlet globemallow during spring and summer. The lack of high quality forbs during spring when nutritional needs are high to some extent explains the low productivity of New Mexico mule deer herds compared to those in northwestern states such as Oregon, Idaho, and Montana (Wallmo 1978).

Elk greatly altered their consumption of browse and grass during the year (Table 2). Browse dominated elk diets in spring and summer while grass was the largest component of elk diets in fall and winter. Like the diets of mule deer, elk diets in summer contained high amounts of oak, mountain mahogany, Russian olive, and skunkbush sumac. Mullein was important in elk diets in autumn and winter, probably because it protruded above the snow. In late autumn and winter during our study, there were alternating periods when the ground was covered with snow and free from snow. We attribute the relatively low amount of grass in summer elk diets to lack of grass growth because of below-average precipitation in both years of study. Elk diets on piñon-juniper rangeland in southwestern New Mexico were dominated by browse in summer when perennial 
Table 2. Seasonal comparison of mule deer and elk diet percent botanical composition for data pooled across years (1998 and 1999).

\begin{tabular}{|c|c|c|c|c|c|c|c|c|}
\hline \multirow[b]{2}{*}{ Lifeform/species } & \multicolumn{2}{|c|}{ Summer } & \multicolumn{2}{|c|}{ Autumn } & \multicolumn{2}{|c|}{ Winter } & \multicolumn{2}{|c|}{ Spring } \\
\hline & Elk & $\begin{array}{l}\text { Mule } \\
\text { deer }\end{array}$ & Elk & $\begin{array}{l}\text { Mule } \\
\text { deer }\end{array}$ & Elk & $\begin{array}{l}\text { Mule } \\
\text { deer }\end{array}$ & Elk & $\begin{array}{l}\text { Mule } \\
\text { deer }\end{array}$ \\
\hline & $---\cdot$ & $---\cdot$ & --- & $----{ }^{\circ}$ & & $-I_{0}$ & 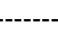 & ----- \\
\hline \multicolumn{9}{|l|}{ Shrubs/trees } \\
\hline $\begin{array}{l}\text { One-seed juniper } \\
\text { (Juniperus monosperma) }\end{array}$ & 3 & $T^{1}$ & 2 & 2 & $\mathrm{~T}$ & 5 & $1^{\mathrm{a}}$ & $10^{b}$ \\
\hline Oak species (Quercus spp.) & 13 & 17 & 12 & 22 & 6 & 7 & 11 & 6 \\
\hline $\begin{array}{l}\text { Mountain mahogany } \\
\text { (Cercocarpus montanus) }\end{array}$ & $12^{\mathrm{a}}$ & $23^{\mathrm{b}}$ & $3^{\mathrm{a}}$ & $24^{\mathrm{b}}$ & $2^{\mathrm{a}}$ & $13^{b}$ & 4 & 5 \\
\hline $\begin{array}{l}\text { Apache plume } \\
\text { (Fallugia paradoxa) }\end{array}$ & 2 & 4 & 1 & 0 & 7 & 6 & 3 & 2 \\
\hline $\begin{array}{l}\text { Russian olive } \\
\text { (Elaeagnus angustifolia) }\end{array}$ & $4^{\mathrm{a}}$ & $15^{\mathrm{b}}$ & $1^{\mathrm{a}}$ & $18^{\mathrm{b}}$ & 3 & 4 & 7 & 9 \\
\hline $\begin{array}{r}\text { Skunkbush sumac } \\
\text { (Rhus trilobata) }\end{array}$ & $6^{\mathrm{a}}$ & $14^{\mathrm{b}}$ & 0 & 4 & $1^{\mathrm{a}}$ & $6^{b}$ & 0 & 0 \\
\hline $\begin{array}{l}\text { Ponderosa pine } \\
\text { (Pinus ponderosa) }\end{array}$ & 6 & $\mathrm{~T}$ & 8 & 1 & $8^{a}$ & $19^{b}$ & 16 & 15 \\
\hline Total shrubs & 61 & 74 & $32^{\mathrm{a}}$ & $78^{\mathrm{b}}$ & $32^{\mathrm{a}}$ & $61^{b}$ & 53 & 60 \\
\hline Forbs & & & & & & & & \\
\hline Mullein (Verbascum thapsus) & 4 & $\mathrm{~T}$ & 12 & 2 & 14 & 17 & 7 & 7 \\
\hline $\begin{array}{l}\text { Annual sunflower } \\
\text { (Helianthus annuus) }\end{array}$ & 2 & 7 & 3 & 1 & 2 & $\mathrm{~T}$ & 0 & 0 \\
\hline $\begin{array}{l}\text { Scarlet globemallow } \\
\text { (Spaeralcea coccinea) }\end{array}$ & 3 & 9 & 6 & 10 & 3 & 0 & 5 & 5 \\
\hline $\begin{array}{l}\text { Purple prairie clover } \\
\text { (Petalostemum purpureum) }\end{array}$ & 1 & 0 & 3 & 2 & $4^{\mathrm{a}}$ & $10^{\mathrm{b}}$ & 0 & 4 \\
\hline Total forbs & 19 & 26 & 31 & 20 & 29 & 29 & 19 & 33 \\
\hline Grasses & & & & & & & & \\
\hline $\begin{array}{l}\text { Slender wheatgrass } \\
\text { (Agropyron trachycaulum) }\end{array}$ & $\mathrm{T}$ & 0 & 5 & 1 & 6 & 5 & 3 & 2 \\
\hline $\begin{array}{l}\text { Orchard grass } \\
\text { (Dactylis glomerata) }\end{array}$ & 2 & 0 & 3 & 1 & 4 & 2 & 3 & 3 \\
\hline Total grasses & $20^{\mathrm{a}}$ & $\mathrm{T}^{\mathrm{b}}$ & $37^{a}$ & $2^{b}$ & $39^{a}$ & $10^{\mathrm{b}}$ & $28^{\mathrm{a}}$ & $7^{b}$ \\
\hline
\end{tabular}

${ }^{1} \mathrm{~T}$ indicates trace.

${ }^{a, b}$ Means with different lowercase letters within the same season and row are significantly different at $P<0.05$

grass growth was depressed by drought (Tafoya 2000). Oak (primarily Gambel oak, a deciduous shrub) was consumed in summer and fall when leaves were intact on plants.

Elk and mule deer differed $(P<0.05)$ in their consumption of several plant species within seasons (Table 2). However, the practical importance of most of these differences is not clear. Forbs were important in both mule deer and elk diets throughout the year (Tables 1 and 2). Forbs play a critical role in mule deer productivity because of their high crude protein concentrations and low fiber levels compared to grasses and shrubs (Hanley 1982). Because of their larger size and higher rumen-reticular volume to body-weight ratio, elk can survive on low-quality forages (grasses) that have lower digestibility and are not consumed by mule deer (Hanley 1982; Mubanga et al. 1985). However, elk will opportunistically consume high-quality forage (forbs) essential to mule deer
Table 3. Percent similarity of mule deer and elk diets within seasons and years on the Los Alamos National Research Laboratory.

\begin{tabular}{lccc}
\hline & 1998 & 1999 & Mean \\
\hline Summer & 72 & 70 & 71 \\
Autumn & 51 & 69 & 60 \\
Winter & 65 & 62 & 64 \\
Spring & 57 & 63 & 60 \\
Mean & 61 & 66 & 64 \\
\hline
\end{tabular}

productivity and survival. Scarlet globemallow is a forb high in nutritive quality (Howard et al. 1990) in short supply on our study area that is important in both elk and mule deer diets (Tables 1 and 2). On our study area, populations of both mule deer and elk have been in an upward trend during the last 10 years (Harrod 2002). We attribute this to conservative to moderate use of forage species.

Our research is consistent with other New Mexico studies in showing high foraging similarity between deer and elk (Table $3)$. On woodland rangelands in south-central New Mexico, Tafoya (2000) found that elk and mule deer had dietary overlaps of over $60 \%$ throughout the year and shared 4 of the top 5 forage species. On a mountain-browse rangeland in north-central New Mexico, Stephenson et al. (1985) found that wintering elk and mule deer had a $63 \%$ dietary overlap. They shared 4 of the top 5 forage species.

We recognize some possible limitations of our study. We consider the primary potential limitations to be factors that can reduce accuracy of microhistological analyses of fecal samples (Gill et al. 1983; Holechek and Valdez 1985; Alipayo et al. 1992). These include difficulty in differentiating some grass species, overestimation of forbs with stellate trichomes or hairs, underestimation of highly digestible forbs, and underestimation of shrubs and trees when a high proportion of woody material is consumed. We do not believe any of these factors greatly influenced the accuracy of microhistological analyses in our study. Grass species on our study area were generally dissimilar and could be readily distinguished. It is possible that purple prairie clover, a high-quality legume, was underestimated. Some of the forbs, particularly scarlet globemallow, can be overestimated because of profuse trichomes. However, use of the frequency addition procedure in diet calculation as discussed by Holechek and Gross (1982a) minimized this source of bias based on work with hand-compounded diets. Because woody parts from shrubs and trees have a low proportion of identifiable epidermal material, they can cause underestimation of browse in fecal samples (Holechek and Valdez 1985). This problem is most likely to occur on rangelands where browsing has been heavy to severe with old growth comprising a large part of the diet. In our study, browsing was moderate and mostly currentyear growth was consumed. Fecal analyses have accurately estimated ruminant diets with a high browse component that was current-year growth (Alipayo et al. 1992).

\section{MANAGEMENT IMPLICATIONS}

Our study indicates that diets of mule deer and elk are not complementary on woodland rangelands in northern New 
Mexico. This is because of dietary overlaps of more than $50 \%$ throughout the year and because mule deer and elk shared 3 of the top 5 key forage species when diets were pooled across seasons and years.

The outcome of our study may have been different if livestock grazing occurred on the LANL. In a study of cattle food habits on woodland rangelands in south-central New Mexico, Neel et al. (1991) found in the fall-winter period, browse composed $50 \%-80 \%$ of cattle diets. Mountain mahogany and oak were primary browse species in cattle diets. A more recent study on this same area showed that mountain mahogany and oak were the 2 primary species consumed by both mule deer and elk (Tafoya 2000). These studies and our research indicate that both cattle and elk numbers must be carefully adjusted when managing mule deer on woodland rangelands in New Mexico.

Under moderate grazing intensity, as on our study area, mule deer can increase in the presence of elk. If populations of mule deer or elk continue to increase, or if other herbivores such as livestock are added to the system, the degree of dietary overlap may change. Because elk are more flexible in the type of forages they can eat, mule deer are likely to be harmed to a greater extent as herbivore density increases.

\section{LITERATURE CITED}

Alipayo, D., R. Valdez, J. L. Holechek, and M. Cardenas. 1992. Evaluation of microhistological analysis for determining ruminant diet botanical composition. Journal of Range Management 45:148-152.

Balice, R. G., S. G. Ferran, and T. S. Foxx. 1997. Preliminary vegetation and land cover classification for the Los Alamos region. Los Alamos, MM. LA-UR-974627. $52 \mathrm{p}$.

BIGGS, J. 1996. Biological and floodplain/wetland assessment for environmental restoration program. Operable Unit 1071. TAs 0, 19, 26, 73, and 74. Los Alamos, NM. LA-UR-93-1168. $153 \mathrm{p}$.

Bowen, B. B. 1990. Los Alamos climatology. Los Alamos, NM: Los Alamos National Laboratory. LA-11735-MS. 42 p.

Bubenik, A. B. 1982. Physiology. In: J. W. Thomas and D. E. Toweill [eds.]. Elk of North America: Ecology and management. Harrisburg, PA: Stackpole Books. p. $125-179$.

Carpenter, L. H. 1997. Deer in the west. Proceedings of 1997 Deer/Elk Workshop. Arizona Game and Fish Department, Rio Rico, AZ. p. 1-10.

Dearden, B. L., R. E. Pagau, and R. M. Hansen. 1975. Precision of microhistological estimates. Journal of Wildlife Management 39:402-407.

De Vos, J. C., JR., M. R. Conover, and N. Headrick [eds.]. 2003. Mule deer conservation: Issues and management strategies. Logan, UT: Berryman Institute Press, Utah State University. $240 \mathrm{p}$.

Foxx, T. S. 1996. Biological and floodplain/wetland assessment for environmental restoration program. Operable Unit 1122. TA-33 and TA-70. Los Alamos, NM. LA-UR-93-106. $69 \mathrm{p}$.

Foxx, T. S. 2000. Out of the ashes: a story of natural recovery. Los Alamos, NM. LALP-01-20. $37 \mathrm{p}$.

Gill, R. B., L. H. Carpenter, R. M. Bartmann, D. L. Baker, and G. G. Schoonveld. 1983. Fecal analysis to estimate mule deer diets. Journal of Wildlife Management 47:902-915.

Gretchen, S., And B. E. Dahl. 1980. Key to selected plant species of Texas using plant fragments. Lubbock, TX: The Museum of Texas Tech University, Occasional papers, No. 64. $37 \mathrm{p}$.

Hanley, T. A. 1982. The nutritional basis for food selection by ungulates. Journal of Range Management 35:146-152.

Harrod, L. A. 1998a. Deer population composition survey summary: 1988-1998. Santa Fe, NM: New Mexico Department of Game and Fish. 129 p.
HarRod, L. A. 1998b. Elk population composition survey summary: 1988-1998. Santa Fe, NM: New Mexico Department of Game and Fish. 139 p.

HARROD, L. A. 2002. Big game sightability index survey summary report, 19982002. Santa Fe, NM: New Mexico Department of Game and Fish. 280 p.

HobBs, N. T., and L. H. Carpenter. 1986. Viewpoint: animal unit equivalents should be weighted by dietary differences. Journal of Range Management 39: 470-471.

HOLECHEK, J. L. 1982. Sample preparation techniques for microhistological analysis. Journal of Range Management 35:267-268.

Holechek, J. L., and D. Galt. 2000. Grazing intensity guidelines. Rangelands 22(3):11-14.

HoleChEK, J. L., AND B. D. Gross. 1982a. Evaluation of different calculation procedures for microhistological analysis. Journal of Range Management 35: 721-723.

HoleCheK, J. L., AND B. D. Gross. 1982b. Training needed for quantifying simulated diets from fragmented range plants. Journal of Range Management 35: 644-647.

Holechek, J. L., M. Vavra, and R. D. Pieper. 1982. Botanical composition determination of range herbivore diets: a review. Journal of Range Management 35:309-315.

HolecheK, J. L., and R. Valdez. 1985. Magnification and shrub stemmy material influences on fecal analysis accuracy. Journal of Range Management 38: 350-352.

Holechek, J. L., R. D. Pieper, and C. H. Herbel. 2004. Range management: principles and practices. 5th ed. Upper Saddle River, NJ: Prentice-Hall Inc. 607 p.

Howard, V. W., J. L. Holechek, R. D. Pieper, K. Green-Hammond, M. Cardenas, and S. L. BEASOM. 1990. Habitat requirements for pronghorn on rangeland impacted by livestock and net wire in east central New Mexico. Las Cruces, NM: New Mexico Agricultural Experiment Station Bulletin 750.

JoSEPH, J. J. 1995. Seasonal food habits of mule deer at the Corona range and livestock research ranch [thesis]. Las Cruces, NM: New Mexico State University. $56 \mathrm{p}$.

KufeLD, R. C. 1973. Foods eaten by Rocky Mountain elk. Journal of Range Management 26:106-113.

Kufeld, R. C., O. C. Wallmo, and C. Feddema. 1973. Foods of Rocky Mountain mule deer. USDA Forest Service Research Paper RM-111. 31 p.

Leslie, D. M., E. E. Starkey, and M. Vavra. 1984. Elk and deer diets in old-growth forests in western Washington. Journal of Wildife Management 48: 762-775.

Mahgoub, E., R. D. Pieper, J. L. Holechek, J. D. Wright, and V. W. Howard, JR. 1987. Botanical content of mule deer diets in south-central New Mexico. New Mexico Journal of Science 27:21-27.

Mubanga, G., J. L. Holechek, R. Valdez, and S. D. Schemnitz. 1985. Relationships between diet and fecal nutritive quality in mule deer. Southwestern Naturalist 30:573-578.

Neel, J. P., D. M. Manzanares, H. E. Kiesling, J. L. Holechek, G. B. Donart, T. D. Goodman, and M. Southward. 1991. Cattle diets on riparian and upland New Mexico pinyon-juniper range. New Mexico Journal of Science 31:7-19.

Nelson, J. R., and T. A. LeEge. 1982a. Nutritional requirements and food habits. In: J. W. Thomas and D. E. Toweill [eds.]. Elk of North America: Ecology and management. Harrisburg, PA: Stackpole Books. p. 323-367.

Nelson, J. R., and T. A. Leege. 1982b. Relationships of elk and other large herbivores. In: J. W. Thomas and D. E. Toweill [eds.]. Elk of North: Ecology and management. Harrisburg, PA: Stackpole Books. p. 415-441.

Oosting, H. J. 1956. The study of plant communities. San Francisco, CA: W.H. Freeman and Company. $440 \mathrm{p}$.

OLSEn, F. W., and R. M. Hansen. 1977. Food relations of wild free-roaming horses to livestock and big game, Red Desert, Wyoming. Journal of Range Management 30:17-20.

RAYMER, D. F. 1996. Biological and floodplain/wetland assessment for environmental restoration program. Operable Unit 1082. TAs 11, 13, 16, 24, 37, and 38. Los Alamos, NM: LA-UR-93-4182. 99 p.

SAlISBURY, M. 1995. Biological assessment for environmental restoration program. Operable Unit 1111. TAs 6, 7, 22, 58, and 62. Los Alamos, NM: LA-UR-954118. $158 \mathrm{p}$. 
Sparks, D. R., and J. C. Malechek. 1968. Estimating percentage dry weight in diets using a microscopic technique. Journal of Range Management 21: 264-265.

Steel, R. G., and J. H. TorRie. 1980. Principles and procedures of statistics. New York, NY: McGraw-Hill Book Co. 633 p.

Stephenson, T. E., J. L. Holechek, and C. B. Kuykendall. 1985. Diets of four ungulates on winter range in northcentral New Mexico. Southwestern Naturalist 30:55-58.

TAFOYA, J. J. 2000. A comparison of elk, mule deer, and Coues deer diets from pinyon-juniper woodlands in southwestern New Mexico [thesis]. Las Cruces, NM: New Mexico State University. $54 \mathrm{p}$.

Tierney, G. D., And T. S. Foxx. 1980. Status of the flora of the Los Alamos Nationa Environmental Research Park. Vol. I. Los Alamos, NM: Los Alamos Scientific Laboratory. LA-8050-NERP. $60 \mathrm{p}$.

TieRney, G. D., AND T. S. Foxx. 1982. Floristic composition and plant succession on near-surface radioactive waste disposal facilities in the Los Alamos National Laboratory. Los Alamos, NM: LA-9219-MS. 65 p.
Tierney, G. D., And T. S. Foxx. 1984. Status of the flora of the Los Alamos National Environmental Research Park, a historical perspective. Vol. II. Los Alamos, NM: Los Alamos National Laboratory. LA-8050-NERP. 50 p.

Todd, L. W., And R. M. Hansen. 1973. Plant fragments in the feces of bighorns as indicators of food habits. Journal of Wildlife Management 37:363-366.

URNESS, P. J. 1981. Desert and chaparral habitats: food habits and nutrition. In: 0. C. Wallmo [ed.]. Mule and black-tailed deer of North America. Lincoln, NE: University of Nebraska Press. p. 347-366.

Wallmo, O. C. 1978. Mule deer and black-tailed deer. In: J. L. Schmidt and D. L. Gilbert [eds.]. Big game of North America: Ecology and management. Harrisburg, PA: Stackpole Books. p. 31- 41.

Wallmo, O. C., and W. L. Regelin. 1981. Rocky Mountain and intermountain habitats. Part 1: food habits and nutrition. In: R. E. McCabe and L. R. Jahn [eds.]. Mule deer and black-tailed deer of North America. Lincoln, NE: University of Nebraska Press. p. 387-398.

White, G. C. 1981. Biotelemetry studies on elk. Los Alamos, NM: Los Alamos Scientific Laboratory. LA-8529-NERP. 24 p. 